\title{
STRATEGIC RESPONSES TO BALLOT QUESTIONS BY THE PRIVATE SECTOR
}

\author{
Alan N. Hoffman \\ School of Business \\ The University of Connecticut \\ Storrs, Connecticut
}

There has been a renewed interest among researchers to understand how regulation restricts the ability of private industry to do business. Miles [19] recently wrote about the history of the tobacco industry and how it became the first major test of corporate social responsibility. The tobacco manufacturers lost their access to public broadcast media, warnings were placed on their labels, and their image and pride were wounded. Yet, they developed a series of response strategies that concentrated on domain diversification and overseas expansion that changed the look of the big six from single-business firms to globsil-multibusiness corporations.

Mitnick defines regulation as: "... the public administrative policing of a private activity with respect to a rule prescribed in the public interest" ([20], p. 7). Most regulatory scholars ([4],[7]) propose that there exists a system of regulation or life cycle, that is, a series of steps from the initial legislation to the establishment of a regulatory agency. Farris and Sampson [9], Shepard [26], and Wilcox and Shepard [31] have each developed models of the distinct stages of regulation. However, there has been little attention paid to the role of regulatory initiatives and referenda in the regulatory literature and their effects on the performance of private industry. The present article, designed with this shortcoming in mind, shifts the focus away from the traditional regulatory process and takes an in-depth look at this non-traditional method of regulation.

\section{Background}

In the past ten years there has been a significant increase in the number of ballot questions whose intent has been to regulate the activities of private industry. Such initiatives can be extremely costly. Since 1978, there have been more than fifty ballot proposals that have directly affected the regulation of several key industries: banking, defense, bottling, farming, cable television, telecommunications, and tobacco.

There are two explanations why the threat of circulating initiative petitions is an integral part of the strategy of lawmaking. The first reason revolves around a state legislature's reluctance to adopt special interest legislation. The initiative process has proved to be an extremely valuable mechanism for representing special interests in our society. Laws to mandate the return of bottles and cans is an example of a regulation that has been adopted by means 
of the initiative process. The second reason for the resurgence of initiatives is that special interest groups often wish to have their proposals adopted in the exact form they were written, rather than "having them amended to death." Lee [15] argues that those groups who utilize initiatives most are not significantly different form those groups who normally lobby state legislatures.

\section{Initiative Campaigns in the Private Sector}

The renewed interest in the initiative process may arise from the large amounts of money spent by both sides in waging these legislative battles in the public arena. For example, California voters have been subjected to several extraordinarily large and expensive regulatory initiative campaigns in the past few years. In 1980 , the tobacco manufacturers spent more than $\$ 6$ million to defeat a proposal to limit smoking in public areas. Additionally, in the primary election of 1980 , more than $\$ 6$ million was spent to defeat an oil profits tax proposal.

Regulatory initiatives are not unique to California. In 1982, there were regulatory proposals in ten other states. One popular initiative question concerns returnable bottles. Proponents of the bottle bills generally argue that returnable bottles conserve natural resources and result in a cleaner environment. Opponents generally take an economic approach and claim that laws requiring returnable bottles lead to price increases in excess of the bottle deposit to cover the increased costs associated with storage, transportation, and recycling facilities. Such states as Michigan, Massachusetts, Maine, and lowa all have returnable bottle laws (Michigan and Massachusetts by referendum). It should be noted that these proposals are often not enacted on their first ballot at tempt.

In 1983, the voters of Cambridge, Massachusetts, voted down a citywide referendum that called for Cambridge to become a Nuclear Free Zone which would have outlawed any work, including research, on nuclear weapons or their components within the city limits after October, 1985. If Cambridge had approved the proposal, Draper Laboratories, a privately owned spinoff of MIT, would have been forced to leave the city.

The banking industry has also become the target of several initiative campaigns. In three states, Washington, Michigan, and Colorado, there have been ballot questions that would place restrictions on banking operations. In Colorado, voters defeated a proposal which would have allowed branch banking. In 1982, the voters of the state of Washington defeated a proposal which would have limited retail credit interest rates.

The citizens of Nebraska, who have witnessed large amounts of their fertile farm land being bought up by corporations, voted in 1982 to prohibit corporations (other than family farm corporations) from purchasing farm and ranch land in their state. It is now evident that initiative campaigns can cost several million dollars to wage. Some of the most expensive initiative campaigns are outlined in Table 1. 
Table 1: Recent Initiative Campaigns With Cost Greater Than $\$ 5$ Million $^{a}$

\begin{tabular}{|lllcr|}
\hline Year & State & \multicolumn{1}{c}{ Issue } & Outcome & \multicolumn{1}{c|}{ Cost } \\
\hline 1984 & Arizona & Control Health Costs & Failed & $>\$ 5,000,000$ \\
1984 & California & Lottery & Passed & $>\$ 10,000,000$ \\
1982 & California & Gun Control & Failed & $\$ 10,000,309$ \\
1982 & California & Returnable Bottles & Failed & $\$ 7,076,574$ \\
1982 & Michigan & Ban Automatic Fuel & Failed & $\$ 7,409,002$ \\
& & Increases/Elect PSC & & \\
1981 & Ohio & Competitive Worker's & Failed & $\$ 6,000,000$ \\
& & Comp. Insurance & & \\
1980 & California & Rent Control & Failed & $\$ 6,835,433$ \\
1980 & California & Oil Profits Tax & Failed & $\$ 6,067,356$ \\
1980 & California & Restrict Smoking & Failed & $\$ 6,000,000$ \\
\hline
\end{tabular}

aSource: National Center for Initiative Review, Englewood, CO, 1986

\section{The Use of Initiative and Referendum in the Regulation of Business}

Ever since the Brandeis Court upheld government regulation of business without infringement of "due process," businesses have faced increasing costs of regulation. Energy, transportation, pharmaceuticals, banking, and telecommunications are examples of a few industries that are presently regulated.

According to a 1976 study by the Congressional Budget Office, regulation of business generally takes one of the following forms:

1. [It] impacts the operating business environment of broad sectors of private enterprise, including market entry and exit; rate price, and profit structures; and competition;

2. [It] impacts specific commodities, products, or services through permit, certification, or licensing requirements; and

3. [It] involves the development, administration, and enforcement of national standards, violation of which could result in civil or criminal penalties which result in the types of impact described above $([20]$, p. 2).

In most legislative bodies there is a maze of parliamentary rules and procedures that traditionally have been used by the minority to prevent or delay a vote on an issue that is favored by the majority ([30], p. 14). Strong supporters of our democratic system of government find this manipulation of the rules to be one of the most serious breakdowns in the representative system of government [30]. The referendum and the right of initiative were developed to close this legislative loophole. 
By the mid-nineteenth century, it was commonplace to require that state constitutional amendments be approved by the voters.... By 1900, Americans were no strangers to the concept of approving changes in their fundamental laws by use of the referendum. That they should have the power of initiating such changes was, to many, a logical extension of their power; the right of initiative was adopted quickly in twenty-one states. Neither the initiative nor the referendum, however, has ever been employed at the national level ([15], p. 46).

It is important to distinguish between the initiative and the referendum processes. The initiative is the sole vehicle available to the electorate to propose legislation without the consent of the legislature. The referendum, on the other hand, "is merely a popular veto on the acts of a legislative body. It's an instrument of negation. It is conservative, while the initiative is radical" ([30], p. 131).

In an attempt to determine the percent of initiatives that eventually become law, Magelby, Klein, and Thomas analyzed initiative results over a recent five year period and found that, when bottle bills were placed in the regulation category, "the success rate for business/labor regulation would be almost 35 percent-by far the best success rate for all categories" ([16], p. 23).

In 1982, less than 30 percent of all proposals titled in initiative states actually qualified for ballot placement. There are four potential types of requirements for qualified ballot placement which, to a certain degree, vary from state to state. These requirements include (1) total number of required signatures, (2) statewide distribution of signatures, (3) certification of signatures, and (4) length of petitioning period.

Every initiative state has a minimum number of signatures required to place an initiative on the statewide ballot. The number of required signatures is usually a function of the number of votes cast for governor during the previous election. Statewide distribution of signatures is required in several states to prevent voters from acting on issues that affect only a small segment of the state population. Other states, however, have no distribution requirement, making it significantly easier to place an initiative on the statewide ballot (i.e., signatures may come from only one county in the state). Requirements which are used to validate either all or a small "random" sample of signatures to certify authenticity are not standardized across states. Finally, in three states (Ohio, Florida, and Montana) signatures gathered in an unsuccessful petition drive can be carried forward and used in future initiative campaigns to meet signature requirements. In Maine, signatures can be carried forward for one year and used in renewed initiative campaigns.

\section{A Model of Private Sector Strategic Responses to Initiative Petition Responses}

Initiative campaigns can be extremely expensive to wage. However, businesses that are unsuccessful in defending themselves from attacks via the 
ballot box may find the implementation of regulations even costlier. Businesses can scarcely afford to react to special interest groups action, instead, an anticipatory strategy is necessary.

... (T)he first duty of strategic management is to stay abreast of organizational resources (potential as well as realized) and the opportunities and risks presented by organizational environments (potential as well as operational) ([19], p. 14).

The policy problems of business, like those of policy in public affairs, have to do with the choice of purposes, the molding of organization identity, the unending definition of what needs to be done, and the mobilization of resources for the attainment of goals in the face of aggressive competition or adverse circumstances ([3], p. iv).

A reactive campaign may have adverse effects on the business climate and should, if possible, be avoided by taking proactive measures at the earliest opportunity. Since most modern business is conducted in dynamic an uncertain environments, Thompson [27] argues that organizations should develop coping strategies to reduce the impact of uncertainty. Many authors suggest that organizations can reduce uncertainty in two ways. First, organizations may reduce uncertainty through the adaptation of specified organizational structures. Second, uncertainty can be reduced through the formulation of strategies aimed at altering the organization's structural environments to bring about a response-sensitive organizational-environment alignment $([1],[18],[19,[23],[27])$.

Given the complexity of modern political environments, a model of how corporations might respond to an initiative campaign is illustrated in Figure 1. This model is based on a 1982 case study of privately owned energy companies in Michigan and consists of the following six phases:

- Prevention

- Organization building

- Coalition building

- Influencing public opinion

- Legislative action

- Mounting an opposition campaign 
MODEL OF STRATEGIC RESPONSES TO BALLOT QUESTIONS

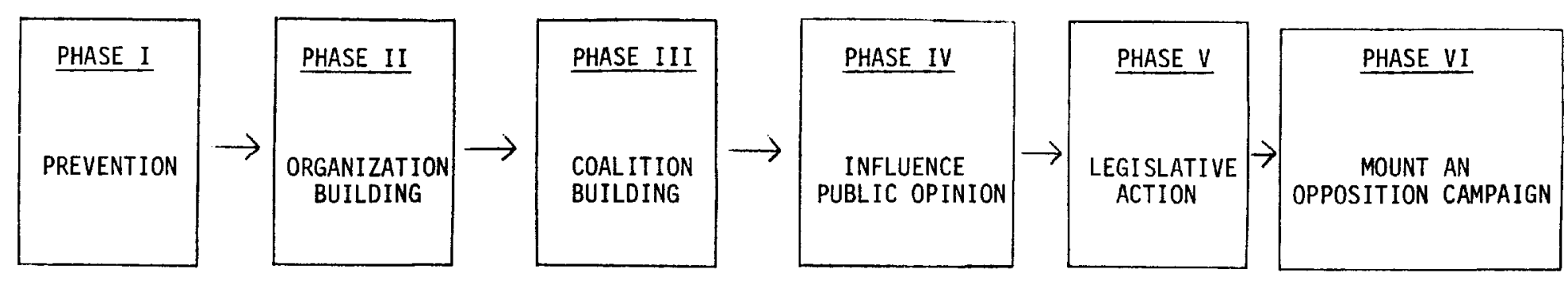

I. PREVENTION

1. Open lines of communication.

2. Joint legislation.

3. Negotiation.

4. Co-optation.

5. Take the public pulse.
II. ORGANIZATION

$$
\text { BUILDING }
$$

1. Appoint executive.

2. Establish interorganizational linkages.

3. Retain legal counsel.

4. Establish political steering committee

5. Create a separate identity.
III. COALITION BUILDING

1. Employees.

2. Allies and vendors.

3. Fundraising.

4. Opinion leaders.

5. Newspaper endorsements.

6. Spokesmen.
V. LEGISLATIVE ACTION

1. Compromise legislation that would render the initiative unnecessary.

2. Legislative alternative.
VI. MOUNT AN OPPOSITION CAMPAIGN

1. Retain professional campaign advice.
IV. INFLUENCE PUBLIC OPINION

1. Citizens commission.

2. Public relations campaign 


\section{Phase I: Prevention}

In the course of normal legislative lobbying by special interest groups, the threat of circulating an initiative petition has often been used as an effective coercive tactic. Modern business must be aware of this potential political occurrence and take steps to monitor such actions [10]. The needs and wants of special interest groups must be considered when formulating corporate policy.

Organizations that have no formal lobbying mechanism should subscribe to a legislative or an initiative monitoring service. There are several monitoring services, such as the National Center for Initiative Review in Englewood, Colorado, that track circulating initiative petitions and publish a monthly newsletter on their activity. Once there is evidence that petitions are circulating that might affect an organization's operations, a public opinion poll should be commissioned. In a large state, like Michigan, a geo-attitudinal poll should be taken. This information is useful to assess the relative strengths and weaknesses of an organization's position. Since everyone in the state votes on the same question, support for or against the proposal might be restricted to a specific region of the state.

A good poll should measure more than just the amount of support or opposition to a question. It should additionally at tempt to understand the public's general feeling toward the organization itself. Polling should be repeated to measure changes in public opinion in response to publicity or implementation of the response strategy. The timetable for these repeated measurements are a function of the funds available for polling. Funds for polling should not be an area of cost cutting since the information garnered is critical in the development and evolution of the organization's responses to adverse initiative campaigns.

\section{Phase II: Organization Building}

If prevention measures are unsuccessful, there are a series of anticipatory steps which can be undertaken to increase the probability of eventual success in an initiative campaign, while minimizing the cost of the effort. The first step is to build an organization capable of responding to any potential political situation. Since businesses most often face political battles with legislatures, and not the general public, a new organizational form is necessary. The size and structure of the new organizational form is a function of two factors: (1) the results of the geo-attitudinal poll, and (2) the signals received from the legislative monitoring program.

The first task for an organization faced with a potential initiative battle is to appoint an executive to coordinate the organization's response strategy. It is important that this executive be practical, have some previous experience in public affairs, and be knowledgeable about the issue and the state's political structure. The executive's first task is to establish ties with firms that would be similarly affected by the initiative. The coordinator should then solicit their support to join in a unified effort to defeat the ballot proposal. Interor- 
ganizational coordination should reduce duplication of effort and maximize human and financial resources.

A political steering committee should be established to give the effort a public identity distinct from the corporate organization(s). The steering committee should seek professional campaign and legal advice. Strategic planning, communications, research, polling, and compliance with intricate campaign finance and election laws are a few areas the committee may want to discuss with professional consultants.

\section{Phase III: Coalition Building}

The political steering committee is responsible for formulating and implementing the response strategy and overseeing all fund-raising and budget decisions. The committee should begin by expanding its base to include other concerned individuals and groups that share in their opposition to the ballot initiative. Two separate coalitions should be formed: One consisting of employees and shareholders, who have a vested interest in the continuing success of the firm, and another consisting of allies and vendors (i.e., other firms who would be either directly or indirectly affected by the new regulation).

A well-built coalition will have far greater resources (i.e., people and money) and stand a better chance for ultimate success than a loosely coupled network of organizations with competing factions. For example, bottlers found that supermarkets and corner grocery stores were natural allies for their cause because these establishments would have to make provisions for storing and sorting returned bottles and cans.

The most important resources a corporation has is its employees, shareholders, and allies. The overall cost of a campaign can be sharply reduced by educating these groups on the issues and training them to handle many of the administrative duties associated with a campaign effort. However, the use of employees can be expensive if they utilize company time to campaign.

Another critical resource to any organized effort is money. A full-fledged campaign can cost millions of dollars, as evidenced most recently in Michigan and California. The establishment of a coalition of allies and vendors can be a valuable source of funds and will allow the cost of a campaign to be spread over several firms, instead of one firm absorbing the full financial burden.

The use of outside political consultants makes sense when the complexity of the task becomes unmanageable for company executives. The response strategy can be formulated and implemented by these outside consultants.

\section{Phase IV: Influencing Public Opinion}

A comprehensive communications plan needs to be created based on the poll results and other research data at the company's disposal. The communications plan should include such items as direct mail, selected advertising, non-corporate endorsements, and third party spokespersons, with no vested interests, speaking out through a coordinated speakers bureau. Radio and television commercials need to additionally be developed to communicate the 
message of the campaign to the different geographic and demographic target groups within the state.

\section{Phase V: Legislative Action}

Businesses can utilize their existing lobbying force to propose compromise legislation that would satisfy both sides and render a campaign unnecessary. A costly campaign showdown should be avoided if at all possible since the results can never be absolutely predicted.

Compromise legislation may not be attainable because of a lack of agreement between the legislature and the Governor. An alternative strategy may be to persuade the legislature to place an alternative question on the ballot that would provide another avenue to defeat the original initiative. All initiative states provide the legislature with the power to place an alternative competing question on the ballot.

\section{Phase VI: Mounting an Opposition Campaign \\ - A Michigan Case Study}

In 1982, consumer advocates in the state of Michigan successfully placed an initiative on the statewide ballot that, if adopted, would have adversely affected the economic stability of Michigan's three major privately-owned energy providers: The Detroit Edison Company, Consumers Power Company, and The Michigan Consolidated Gas Company. This initiative-based proposal, labeled Proposition $D$, called for a ban on all automatic rate increases except when approved at "full cost of service" hearings. The initiative also limited the frequency of these hearings.

The consumer groups in Michigan achieved a measure of success, despite spending only about $\$ 100,000$, because their strategy and organization were both highly effective. They were successful in two ways: (1) they forced the private energy companies to support legislation that would abolish automatic fuel adjustments, and (2) they obtained free publicity from their legal maneuvers which allowed them to capitalize on a general hostility among voters toward energy providers. This second area of success arose from the practice of exerting legal challenges to the energy companies' ballot alternative. Additionally, the consumer groups were organized at the grass-roots level which allowed them wide exposure and valuable free labor.

In June, 1982, after an intensive lobbying effort by energy companies, the Michigan state legislature voted to place an alternative referendum, labeled Proposition $\mathrm{H}$, on the November ballot. The consumer groups challenged the constitutionality of the alternative referendum in the courts and in September, 1982, the Michigan Supreme Court ruled that the alternative proposal should be placed on the ballot to give the voters a choice.

The energy companies made four strategic decisions from the outset that were critical to their ultimate success in defeating the initiative question: 
- They pooled and committed whatever human and financial resources were necessary to wage a unified campaign

- They sought outside counsel to plan and execute their strategy

- They fully utilized their legislative options

- They established a public coalition separate from their corporate identities to broaden their base of support, allowing a diverse constituency to join their effort (i.e., labor, business, and civic groups)

The energy companies response strategy was unique in that:

- It allied three competitors against a common problem

- It developed a coalition of labor and business support

- It supplied the voters an alternative ballot question to vent their frustration toward higher energy bills

- It was the second most costly initiative campaign to that date, costing $\$ 7,409,002$

\section{Results}

In November, 1982, 51 percent of the voters of Michigan gave Proposal D, the citizen initiative, a yes vote while the energy companies' alternative referendum, Proposal $\mathrm{H}$, received nearly 57 percent. Legal precedent in Michigan has held that if two similar ballot questions both receive a majority vote, the question with the greatest number of affirmative votes prevails. Proposal $\mathbf{H}$ outpolled Proposal D by 198,000 votes. It was an expensive victory for the energy companies.

\section{Discussion}

Private energy companies, like many other industries, operate in full view of the public and are prepared to respond to regulation from normal government channels. Most corporations have established public relations departments and have in-house lobbyists that deal with regulatory agencies, state legislatures, and Congress. While many other organizations operate in the public domain, they are not used to being regulated by the general public. Most organizations have established contacts with local politicians, opinion leaders, and newspapers. These are not the type of citizen groups that usually initiate a regulatory petition drive.

For example, the Dart-Kraft Company is used to responding to regulation concerning the price and quality of dairy products by the Food and Drug Administration (FDA). However, they did not perceive that they would become part of the solution to another important problem-hunger in the United States-by becoming directly affected by President Ronald Reagan's cheese 
giveaway program. Dart-Kraft's cheese sales decreased nearly six percent when the giveaway began and the lobbyists of Dart-Kraft were unsuccessful in their attempt to influence the Congress and the FDA to modify the program. The inability to revise the program may be attributable, in part, to the immense popularity of the program with the general public.

There have been several changes in the use of the initiative since its inception, from the initial purpose of ratifying constitutional amendments and local charters. Not all states have the right of initiative, nor does there exist a national referendum process. However, initiatives are popular in those states that have them. In California, 85 percent of the voters thought that direct legislation was a good idea [16].

Finally, many businesses are finding that elected representatives no longer respond to lobbyists the way they once did. Today's representatives are listening more to the constituents they represent. Business executives need to learn how to get their message to the general public as a way to influence future legislation rather than relying on the lobbying system. Hopefully, this article is a step in that direction.

\section{References}

1. Aldrich, Howard and Pfeffer, Jeffrey. "Environments of Organizations," Annual Review of Sociology, Vol. 2, Palo Alto, CA: Annual Review Inc., 1976.

2. Anderson, Jack. "Tax Revolt: The Opening of the U.S. Wide Movement," Deseret News, June 13, 1978, p. A3.

3. Andrews, Kenneth R. The Concept of Corporate Strategy, Revised Edition, Homewood, IL: Richard D. Irwin, 1980.

4. Backoff, Robert W. "Operationalizing Administrative Reform for Improved Governmental Performance," Administrative Science Quarterly, Vol. 6, No. 1, May, 1974, pp. 73-106.

5. Bolt, Ernest C., Jr. Ballots Before Bullets: The War Referendum Approach to Peace in America, Charlottesville, VA: The University of Virginia Press, 1977.

6. Butler, David and Ranney, Austin. Referendums: A Comparative Study of Practice and Theory, Washington, DC: American Enterprise Institute for Public Policy and Research, 1978.

7. Davis, Lance E. and North, Douglass C. Institutional Change and American Economic Growth, Cambridge, MA: Cambridge University Press, 1971.

8. Everett, David. "Utilities Use Subtle Offense to Win at the Polls," The Detroit News, November 7, 1982. 
9. Farris, Martin T. and Sampson, Roy J. Public Utilities: Regulation, Management and Ownership, Boston, MA: Houghton Mifflin, 1973.

10. Grefe, Edward A., Fighting to Win: Business Political Power, New York, NY: Harcourt, Brace Jovanovich, 1981.

11. Hoftman, Alan N., Cynthia Spanhel, and Rolf Carlson. "The Answer Book," Unpublished Monograph, Matt Reese and Associates, 1982.

12. Initiative Quarterly, 1.1, Englewood, CO: National Center for Initiative Review, October 1982, pp. 7-8.

13. Kilpatrick, James. "The Year of the Taxpayer," San Francisco Chronicle, June 2, 1978, p. 52.

14. Kraft, Joseph. "Populist Hedonism," Washington Post, June 11, 1978, p. C7.

15. Lee, Alton. The Referendum Device, New York, NY: Macmillan Book Co., 1981.

16. Magleby, David B., Walt Klein, and Sue Thomas. "The Initiative in the 1980s: Popular Support, Issue Agendas, and Legislative Reform of the Process," Paper presented at the 1982 Annual Meeting of the American Political Science Association.

17. Mathews, Jay. "Initiative Process Gains Popularity," Washington Post, May 29, 1982.

18. Miles, Raymond E., Charles C. Snow, and Jeffrey Pfeffer. "OrganizationalEnvironment: Concepts and Issues," Industrial Relations, Vol. 13, No. 3, pp. 244-264.

19. Miles, Robert H. Coffin Nails and Corporate Strategies, Englewood Cliffs, NJ: Prentice-Hall, 1982.

20. Mitnick, Barry M. The Political Economy of Regulation, New York, NY: Columbia University Press, 1980.

21. Mitnick, Barry M. "The Strategic Uses of Regulation and Deregulation," Business Horizons, March/April, 1981, pp. 71-83.

22. Navarro, Peter. "Our Stake in the Electric Utility's Dilemma," Harvard Business Review, May/June 1982, pp. 87-97.

23. Pfeffer, Jeffrey, and Leblebici, Huseyin. "The Effect of Competition on Some Dimensions of Organizational Structure," Social Forces, Vol. 52, No. 2, pp. 268-279. 
24. Price, Charles M. "The Initiative: A Comparative State Analysis and Assessment of a Western Phenomena," Western Political Quarterly, Vol. 28, June 1975, pp. 243-263.

25. Quinn, Robert S. "The Initiative: Who Needs It?," Maine Sunday Telegram, March 14, 1982, p. 4D.

26. Shepard, William G. The Treatment of Market Power: Antitrust, Regulation, and Public Enterprise, New York, NY: Columbia University Press, 1975.

27. Thompson, James D. Organizations in Action, New York, NY: McGrawHill, 1967.

28. Vitali, Samuel A., and Vento, Gerald T. "Problems with the Initiative and Referendum Process," Unpublished working paper, Peralta, Gilligan and Vitali, 1982.

29. Walsh, Lawrence R. "The Role of Public Relations in Initiative Campaigns," Unpublished working paper, Hill and Knowlton, 1982.

30. Wilcox, Delos. Government by All the People, New York, NY: DaCapo Press, 1972.

31. Wilcox, Clair, and Shepard, William G. Public Policies Toward Business, third edition, Homewood, IL: Richard D. Irwin, 1966.

32. Will, George. "California Votes to Undo What Has Been Done," Los Angeles Times, June 8, 1978, p. B7. 